\title{
Identifikasi Potensi Bahaya, Risiko dan Pencegahan Kecelakaan Kerja di Peternakan Sapi Potong di Wilayah Boyolali
}

\section{Bayu Andri Atmoko1, I Gede Suparta Budisatria ${ }^{2 *}$}

${ }^{1}$ Program Studi Profesi Insinyur Peternakan, Fakultas Peternakan, Universitas Gadjah Mada

${ }^{2}$ Departemen Produksi Ternak, Fakultas Peternakan, Universitas Gadjah Mada

\begin{tabular}{l}
\multicolumn{1}{c}{ ARTIKEL INFO } \\
\hline Sejarah artikel \\
Diterima 21/07/2021 \\
Diterima dalam bentuk revisi 22/09/2021 \\
Diterima dan disetujui 17/11/2021 \\
Tersedia online 31/12/2021 \\
\hline Kata kunci \\
Analisis bahaya \\
Analisis risiko \\
Kesehatan kerja \\
Keselamatan kerja \\
Sapi potong \\
\hline
\end{tabular}

\begin{abstract}
ABSTRAK
Kesehatan dan keselamatan kerja (K3) adalah pedoman setiap pelaku kerja, salah satunya bidang peternakan. Perusahaan di bidang penggemukan (fattening) sapi potong mempunyai kewajiban dan tanggung jawab menerapkan K3. Tujuan penelitian ini yaitu untuk melakukan identifikasi potensi bahaya dan risiko, analisis bahaya dan risiko, dan merumuskan upaya pengendalian K3 di perusahaan penggemukan sapi potong di wilayah Boyolali. Penelitian dilaksanakan di PT. X di Kabupaten Boyolali, Jawa Tengah. Penelitian dilakukan dengan tiga tahap, tahap pertama dilakukan identifikasi potensi bahaya dan risiko pada berbagai kegiatan, tahap kedua dilakukan penilaian terhadap potensi bahaya dan risiko yang mungkin ditimbulkan dari kegiatan yang teridentifikasi. Tahap ini dilakukan dengan pengamatan langsung, mengikuti seluruh kegiatan pemeliharaan, dan diskusi dengan pimpinan, manajemen maupun dengan pegawai kandang. Tahap ketiga dirumuskan pengendalian bahaya dan risiko yang dapat dilakukan. Analisis dilakukan secara deskriptif. Hasil penelitian menemukan bahwa di PT. X terdapat enam pekerjaan di kandang sapi yang dapat menimbulkan sebanyak 31 potensi bahaya dengan risiko rendah (18) dan sedang (13). Selain itu, upaya penerapan keselamatan dan kesehatan kerja masih sangat minim, belum ada standart operating prosedur (SOP) K3. Penerapan K3 oleh pekerja hanya dengan alat pelindung diri (APD) berupa sepatu kandang. Hal ini memungkinkan terjadi potensi bahaya dan risiko kecelakaan kerja. Disarankan kepada PT. X untuk menyusun SOP K3, mensosialisasikan, menerapkan pada seluruh pekerja dan melakukan pengawasan, monitoring dan evaluasi terhadap penerapan SOP K3. Pekerja kandang diharapkan selalu menggunakan APD saat bekerja. Hal ini sebagaui upaya pencegahan risiko dan bahaya kecelakaan kerja saat melakukan pekerjaan.
\end{abstract}

(C) 2021 Politeknik Pembangunan Pertanian Manokwari

*Email Penulis Korespondensi : budisatria@ugm.ac.id brebayuandri@gmail.com ${ }^{1}$, budisatria@ugm.ac.id ${ }^{2}$ 


\section{ABSTRACT}

Occupational Health and Safety (OHS) is the guideline that needs to be known and implemented by workers, including in the livestock industry sector. The company in fattening beef cattle have the obligation and responsibilities for OHS implementation.. This research (case study) was conducted to identify the potential hazards and risks of work accidents, analyzed the potential hazards and risks, and formulated the prevention of work accidents at PT. X. The research was carried out at PT. $X$ in Boyolali Regency, Central Java, from February to March 2021. The study was conducted in three stages, the first stage was to identify the potential hazards and risks in various activities. The second stage was to assess the potential hazards and risks based on the first stage. The third stage was formulated hazard control and risks that can be done. The research activity included direct observation, participated in the fattening system's production process, and interviewed the company's

\section{PENDAHULUAN}

Kesehatan dan keselamatan kerja (K3) adalah pedoman wajib untuk diketahui dan diimplementasikan oleh setiap pelaku kerja pada industry di berbagai bidang seperti kedokteran, teknik, medis, bahkan dibidang agroindustri. Menurut Ramli (2010b), UndangUndang Keselamatan Kerja No.1 Tahun 1970, Peraturan Menteri Tenaga Kerja Per.05/MEN/1996 tentang Sistem Manajemen Kesehatan dan Keselamatan Kerja telah mengatur program K3. Secara internasional K3 juga diatur dengan International Labour Organization (ILO) Code of Practise, Prevention of Major Industrial Accidents. Peraturan K3 baik secara nasional maupun internasional tersebut ditetapkan di seluruh bidang industri sebagai langkah pencegahan dan pengendalian terjadinya $\mathrm{K} 3$ akibat adanya kenaikan produksi, penggunakan peralatan, management and workers. The data was analyzed descriptively. The results found that there was six work activity in the fattening system's production process that can be caused 31 potential hazards with low (18) and medium (13) risks at PT. X. In addition, the efforts to implement OHS were low. It was not found that the OHS standard operating procedure from the management and the OHS application by workers in the production process was limited with the only use of personal protective equipment (PPE) in the form of boats. This results in potential hazards and the risks of work accidents were possible. It was suggested for the management of PT. X to set, establish and implement the OHS standard operating procedure for their workers. The OHS implementation must be supervised and evaluated periodically. The workers were expected to use PPE every time they do work. It was essential to prevent the hazard and risk of work accidents in the beef cattle production process.

proses penyimpanan maupun penggunaan material berbahaya. Maka dari itu, diperlukan informasi dan petunjuk praktis yang dapat menjelaskan secara lengkap dan jelas mengenai penerapan kesehatan dan keselamatan kerja (K3) di industri peternakan, salah satunya peternakan sapi potong (feedlot).

Kegiatan produksi pada industri bidang peternakan merupakan salah satu kegiatan yang paling berbahaya bagi pekerjanya (Yuliandi dan Ahman, 2019). Pekerjaan di industri peternakan memiliki risiko kecelakaan kerja yang cukup tinggi, namun tidak sedikit pekerja yang mengabaikan aspek keselamatan dan kesehatan mereka. Risiko kecelakaan kerja merupakan gambaran atau ukuran terhadap kemungkinan bahaya yang timbul dan dapat berakibat pada kecelakaan. Risiko juga menjadi ukuran keparahan dari kecelakaan kerja tersebut. Apabila hewan ternak yang dipelihara semakin 
besar, maka tenaga hewan ternak yang dihasilkan juga semakin besar. Pada saat hewan ternak panik akan melakukan pergerakan yang tidak terduga dan mengancam pekerja. Pekerja peternakan sapi potong memiliki pekerjaan yang sangat berisiko dengan adanya interaksi dengan sapi potong tersebut. Sebagai contoh, apabila pekerja sedang berada di dekat sapi sering terjadi kepanikan dan pergerakan secara tiba-tiba. Pergerakan sapi tersebut dapat melukai pekerja, bahkan dengan ukuran sapi yang cukup besar resiko yang ditimbulkan dari kecelakan tersebut bisa berakibat fatal, misalnya sampai meninggal dunia. Sampai dengan saat ini belum ada laporan pasti terhadap korban kecelakaan kerja dari industry peternakan, khususnya peternakan sapi potong. Hal ini terjadi karena belum ada perhatian khusus pada aspek K3 di industri peternakan, mengingat jumlah pekerjanya yang lebih sedikit dibandingkan pada industri lainnya (Pranamyaditia, 2017; Yuliandi dan Ahman, 2019). Dengan beban kerja dan risiko kecelakaan kerja yang tinggi bagi pekerja di industri peternakan seharusnya menjadi alasan untuk lebih memperhatikan aspek K3 baik pada pekerja maupun hewan ternaknya.

Merujuk pada (Peraturan Menteri Tenaga Kerja Republik Indonesia Nomor 05/MEN/1996 Tentang Sistem Manajemen Keselamatan Dan Kesehatan Kerja, 1996), tanggung jawab terhadap K3 adalah mengikat bagi setiap orang. Semua orang wajib terlibat dan berpartisipasi dalam K3. Semua orang wajib bertanggung jawab atas keselamatan dan kesehatan dirinya maupun rekan kerja di lingkungan kerjanya masing-masing karena adanyakegiatan teknis yang melibatkan peralatan/mesin dan sumber daya manusia. Penerapan K3 dalam bidang peternakan belum banyak dilakukan pada skala usaha menengah maupun kecil pada tingkat peternakan rakyat sehingga perlu kajian mengenai identifikasi potensi bahaya, risiko dan pencegahan kecelakan kerja pada praktik usaha peternakan sapi potong penggemukan (feedlot) yang ada di Indonesia.

PT. X adalah perusahaan di bidang penggemukan (fattening) sapi potong yang berlokasi di Kecamatan Cepogo, Kabupaten Boyolali, Jawa Tengah. PT. X berdiri sejak tahun 2014 dengan kapasitas kandang sebanyak 200 ekor. Sistem produksi yang dijalankan oleh perusahaan adalah penggemukan (fattening) sapi potong baik dengan bangsa sapi lokal dengan jangka waktu produksi 4 bulan (sapi penggemukan) dan 8 bulan (sapi qurban) setiap tahun. PT. X mengembangkan usaha dengan mendirikan pabrik pakan konsentrat sapi potong pada tahun 2019 untuk menunjang proses produksi penggemukan maupun dijual untuk masyarakat umum yang membutuhkan. Kapasitas produksi pabrik pakan konsentrat sapi potong sampai dengan saat ini adalah 150 ton per bulan. Skala usaha penggemukan dan produksi pakan konsentrat perusahaan tersebut masih tergolong menengah jika ditinjau dari populasi sapi dan kapasitas produksinya. Sebagai perusahaan (PT), tentu saja PT. X mempunyai kewajiban dan tanggung jawab dalam penerapan $\mathrm{K} 3$.

Tujuan penelitian ini yaitu untuk melakukan identifikasi potensi bahaya dan risiko, analisis bahaya dan risiko, dan 
merumuskan upaya pengendalian $\mathrm{K} 3$ di perusahaan penggemukan sapi potong di wilayah Boyolali, khususnya di PT. X sebagai perusahaan di bidang penggemukan sapi potong. Hasil penelitian ini diharapkan dapat memberi informasi dan gambaran mengenai potensi bahaya, risiko kecelakaan kerja pada perusahaan peternakan sapi potong. Hasil penelitian ini diharapkan juga dapat dijadikan rujukan dan acuan dalam perbaikan manajemen dan pengambilan kebijakan terkait dengan keselamatan dan kesehatan kerja oleh pemangku kebijakan.

\section{METODE}

Penelitian studi kasus dilaksanakan di kandang penggemukan sapi potong PT. X dengan kapasitas 200 ekor sapi potong berlokasi di Kabupaten Boyolali, Jawa Tengah pada bulan Februari sampai Maret 2021. Penelitian studi kasus dilakukan berfokus pada kegiatan dan program terkait dengan pelaksanaan keselamatan kerja pada sistem produksi penggemukan sapi potong. Penelitian studi kasus dilakukan dengan berbagai kegiatan yaitu: 1. melakukan pengamatan langsung (observasi), 2. mengikuti seluruh rangkaian kegiatan pemeliharaan sapi 3. melakukan diskusi (wawancara) baik dengan pimpinan, manajemen maupun dengan pekerja kandang.

Penelitian ini dilakukan dengan beberapa tahapan. Tahap pertama adalah mengidentifikasi potensi bahaya dan risiko pada berbagai kegiatan-kegiatan. Tahap kedua adalah menilai potensi bahaya dan risiko yang mungkin timbul pada berbagai kegiatankegiatan yang teridentifikasi pada tahap pertama. Tahap ketiga yaitu dengan melakukan pengendalian maupun upaya pencegahan bahaya dan risiko yang mungkin dapat dilakukan. Tahapan pada penelitian ini sesuai dengan Ramli (2010b).

Penilaian risiko (risk assessment) adalah analisis dalam menilai risiko dan mengidentifikasi seluruh kegiatan-kegiatan kontrol sebagai upaya dalam menghilangkan sepenuhnya atau hanya mengurangi sebagian risiko yang ada sehingga masih dapat ditoleransi, Penilaian risiko merupakan cara yang dapat digunakan dalam mengelola risiko pada setiap pekerjaan yang dilakukan. Penilaian resiko juga sebagai upaya dalam memastikan kesehatan dan keselamatan serta menghindarkan dari resiko pada saat bekerja bagi para pekerja (Rijanto, 2011). Penilaian risiko digunakan upaya awal dalam menghitung tingkat risiko berdasarkan kemungkinan kejadian (likelihood) dan tingkat keparahan yang ditimbulkan (severity) (Ramli, 2010a). Skala kemungkinan kejadian (likelihood) disajikan pada Tabel 1 dan tingkat keparahan yang ditimbulkan (severity) disajikan pada Tabel 2. Seluruh potensi bahaya yang berhasil teridentifikasi pada tahap pertama dinilai risikonya untuk menentukan seberapa besar tingkat risiko (risk rating) dari bahaya-bahaya tersebut.

Tabel 1. Skala kemungkinan kejadian(likelihood) (Ramli, 2010a)

\begin{tabular}{ccl}
\hline Tingkat & Deskripsi & \multicolumn{1}{c}{ Keterangan } \\
\hline 1 & $\begin{array}{c}\text { Almost } \\
\text { certain }\end{array}$ & Dapat terjadi setiap saat \\
2 & Likely & Kemungkinan terjadi sering \\
3 & Posible & Dapat terjadi sekali-kali \\
4 & Unlikeky & Kemungkinan jarang terjadi \\
5 & Rare & Hampir tidak pernah atau \\
& & jarang sekali terjadi \\
\hline
\end{tabular}


Analisis risiko adalah analisadalam menentukan seberapa besar suatu risiko, di mana resiko tersebut adalah kombinasi antara kemungkinan terjadinya (likelihood) dan keparahan bila risiko tersebut terjadi (severity) (Ramli, 2010a). Risiko dapat dinilai dan disajikan dengan matriks melalui perkiraan probabilitas dan konsekuensi secara kualitatif, dan kemudian diikuti dengan nilai kuantitatif (angka). Teknik dalam melakukan analisa risiko adalah teknik semi kuantitatif, dimana teknik ini dianggap lebih baik dalam menganalisis tingkat risiko disbanding menggunakan teknik kualitatif. Teknik semi kuantitatif mampu memberikan informasi seberapa besar tingkat risiko yang lebih nyata disbanding menggunakan teknik kualitatif. Nilai risiko tersebut disajikan secara numerik (angka), namun nilai tersebut tidak bersifat absolut, misalnya pada risiko A dengan nilai 2 dan risiko B dengan nilai 4, yang tidak serta-merta mempunyai arti bahwa risiko B secara absolut adalah 2 kali lipatnya risiko A (Ramli, 2010a).

Tabel 2. Tingkat keparahan yang ditimbulkan (severity) (Ramli, 2010a)

\begin{tabular}{|c|c|c|}
\hline Tingkat & Deskripsi & Keterangan \\
\hline 1 & Insignificant & $\begin{array}{l}\text { Tidak terjadi ciddera, } \\
\text { kerugian finansial } \\
\text { kecil }\end{array}$ \\
\hline 2 & Minor & $\begin{array}{l}\text { Cidera ringan, } \\
\text { kerugian finansial } \\
\text { sedang }\end{array}$ \\
\hline 3 & Moderate & $\begin{array}{l}\text { Cidera sedang, perlu } \\
\text { penanganan medis, } \\
\text { kerugian finansial } \\
\text { besar }\end{array}$ \\
\hline 4 & Major & $\begin{array}{l}\text { Cidera berat }>1 \text { orang, } \\
\text { kerugian besar, } \\
\text { gangguan produksi }\end{array}$ \\
\hline 5 & Catostrophic & $\begin{array}{l}\text { Fatal > } 1 \text { orang, } \\
\text { kerugian sangat besar, } \\
\text { dan dampak luas yang } \\
\text { panjang dan poses } \\
\text { produksi terhenti }\end{array}$ \\
\hline
\end{tabular}

Penilaian risiko dan bahaya dari potensi kecelakaan kerja dianalisis secara semi kuantitatif, didapat dari penilaian likelihood dan penilaian severity. Setelah melakukan identifikasi bahaya dan risiko pada tahap pertama, pada tahap kedua adalah melakukan penilaian risiko. Penilaian risiko merupakan hasil perkalian dari $\mathrm{S}$ (severity) dan $\mathrm{L}$ (likelihood), hasil perkalian tersebut yaitu RR (risk rating). Tingkat resiko kemudian dikategorikan menjadi 3 yaitu resiko tinggi, resiko sedang, dan resiko rendah. (Ramli, 2010a). Data yang diperoleh pada penelitian ini kemudian dianalisis dan disajikan secara deskriptif kualitatif dan kuantitatif.

\section{HASIL DAN PEMBAHASAN}

PT. X adalah perusahaan di bidang penggemukan (fattening) sapi potong. Sistem produksi yang dijalankan oleh perusahaan adalah penggemukan (fattening) sapi potong baik dengan bangsa sapi lokal dengan jangka waktu produksi 4 bulan (sapi penggemukan) dan 8 bulan (sapi qurban) setiap tahun. Terdapat beberapa orang yang bertanggung jawab dalam pemeliharaan sapi di kandang peternakan sapi potong di PT. X antara lain orang yang bertugas dalam 1. handling sapi (menuntun, menarik, dsb), 2. pemberian pakan hijauan, 3. pemberian pakan konsentrat, 4. membersihkan kandang, 5. melakukan perawatan kesehatan sapi, dan 6 . melakukan perawatan kandang.

Pelaksanaan kegiatan di kandang peternakan sapi potong pegawai atau sumber daya manusia (SDM) sebisa mungkin diharapakan memiliki kompetensi dari segi aspek teknis dalam memelihara ternak, 
meningkatkan animal welfare dan keamanan serta keselamatan. Menurut (Pranamyaditia, 2017), pekerjaan di kandang sapi potong mempunyai risiko tinggi dengan adanya kecelakaan yang terjadi di kandang sapi potong. Kecelakan kerja di knadang sapi potong termasuk kecelakaan industri (industrial accident) yang biasa terjadi di tempat kerja akibat adanya sumber bahaya kerja. Apabila tidak dikendalikan, maka dapat mengakibatkan hal-hal yang tidak diinginkan yang yaitu kecelakaan kerja.

Kesehatan dan keselamatan kerja adalah suatu masalah yang sangat serius dan berkaitan dengan produktivitas dalam proses produksi (Agbola, 2012). Oketunji (2014), menyatakan bahwa seseorang yang bekerja baik dengan resiko kerja yang tinggi ataupun rendah wajib memperhatikan dan memprioritaskan K3 dalam setiap pekerjaannya. Program K3 sangat penting dalam memastikan bahwa perusahaan telah mempersiapkan lingkungan kerja yang aman bagi pekerjanya dan umeminimalkan risiko kecelakaan kerja dan cedera (Machabe \& Indermun, 2013). Bahaya merupakan sesuatu hal yang dapat mengakibatkan cedera pada manusia atau kerusakan pada alat/mesin maupun pada lingkungan (Rijanto, 2011). Identifikasi bahaya dilakukan pada beberapa pekerjaan yang terdapat di kandang sapi potong PT. X, dan hasilnya disajikan pada Tabel 3.

Tabel 3. Identifikasi bahaya dan resiko yang berpotensi pada beberapa pekerjaan di kandang sapi potong PT. X

\begin{tabular}{|c|c|c|c|}
\hline No & Pekerjaan & Potensi bahaya & Konsekuensi akibat (resiko) \\
\hline 1 & Handling sapi & $\begin{array}{l}\text { Tertanduk, tertendang, terinjak, } \\
\text { terhimpit, terpeleset, terlilit tali }\end{array}$ & $\begin{array}{l}\text { Memar, luka gores, patah tulang, } \\
\text { lebam, luka dalam, pendarahan, } \\
\text { pingsan, kematian }\end{array}$ \\
\hline 2 & $\begin{array}{l}\text { Pemberian } \\
\text { pakan Jerami }\end{array}$ & $\begin{array}{l}\text { Tertusuk, kebakaran, kelilipan, } \\
\text { terpeleset, serangan sapi }\end{array}$ & $\begin{array}{l}\text { Memar, luka gores, luka sobek, luka } \\
\text { bakar, gatal-gatal, patah tulang, } \\
\text { lebam, luka dalam, pingsan, } \\
\text { kematian }\end{array}$ \\
\hline 3 & $\begin{array}{l}\text { Pemberian } \\
\text { pakan } \\
\text { konsentrat }\end{array}$ & $\begin{array}{l}\text { Terhirup debu pakan, gangguan } \\
\text { serangga, kelilipan, terpeleset, } \\
\text { serangan sapi }\end{array}$ & $\begin{array}{l}\text { Memar, luka gores, luka bakar, patah } \\
\text { tulang, lebam, luka dalam, pingsan, } \\
\text { kematian }\end{array}$ \\
\hline 4 & $\begin{array}{l}\text { Pembersihan } \\
\text { kandang }\end{array}$ & $\begin{array}{l}\text { Terpeleset, serangan sapi, } \\
\text { terhirup bau tidak sedap, } \\
\text { keracunan gas } \mathrm{NH}_{3} \text { dan } \mathrm{CH}_{4}\end{array}$ & $\begin{array}{l}\text { Memar, luka gores, patah tulang, } \\
\text { lebam, luka dalam, pendarahan, } \\
\text { pusing, pingsan, kematian }\end{array}$ \\
\hline 5 & $\begin{array}{l}\text { Perawatan } \\
\text { kesehatan sapi }\end{array}$ & $\begin{array}{l}\text { Tertusuk jarum suntik, } \\
\text { tertanduk, tertendang, terinjak, } \\
\text { terhimpit, terpeleset }\end{array}$ & $\begin{array}{l}\text { Memar, luka gores, luka tusuk, luka } \\
\text { sobek, patah tulang, lebam, luka } \\
\text { dalam, pingsan, kematian }\end{array}$ \\
\hline 6 & $\begin{array}{l}\text { Perawatan } \\
\text { kandang }\end{array}$ & $\begin{array}{l}\text { Terjatuh, tertimpa bangunan, } \\
\text { tersetrum, tertusuk, terpukul } \\
\text { palu }\end{array}$ & $\begin{array}{l}\text { Memar, luka gores, luka tusuk, luka } \\
\text { sobek, patah tulang, lebam, luka } \\
\text { dalam, pingsan }\end{array}$ \\
\hline
\end{tabular}


Tabel 3 menyajikan identifikasi risiko dan bahaya yang berpotensi pada beberapa pekerjaan di kandang sapi potong. Pada bagian identifikasi ini difokuskan pada sisi Kecelakaan Akibat Kerja (KAK), sehingga tidak memasukan Penyakit Akibat Kerja (PAK). Pekerjaan yang teridentifikasi pada Tabel 3 secara berurutan adalah handling sapi, pemberian pakan hijauan, pemberian pakan konsentrat, pembersihan kandang, perawatan kesehatan sapi, dan perawatan kandang. Beberapa pekerjaan pada Tabel 3 berkaitan langsung dengan ternak sapi maupun dengan peralatan yang ada di kandang. Sapi berpotensi menimbulkan risiko dan bahaya. Masingmasing pekerjaan tersebut kemudian diidentifikasi dan analisis dampak dan konsekuensi akibat dari potensi bahaya dan kecelakaan kerja yang ditimbulkan. Hasil penelitian ini sama dengan (Pranamyaditia, 2017) yang melaporkan hasil identifikasi potensi bahaya pekerjaan di salah satu perusahaan penggemukan sapi potong di Kota Kediri yang meliputi pekerjaan mencari dan mencacah rumput untuk pakan sapi, memindahkan sapi, mencampur pakan konsentrat, pembersihan kandang, pengolahan limbah sapi, pemeriksaan kesehatan sapi dan pemeliharaan atau perbaikan kandang. Yuliandi dan Ahman, (2019), melaporkan bahwa pekerjaan dalam penyusunan dan penyimpanan material berbahaya dan pembuangan limbah sapi menjadi titik kritis pada penilaian risiko K3 di Balai Besar Inseminasi Buatan (BBIB) Lembang, Jawa Barat. Hal ini terlihat dari penyusunan dan penyimpanan zat berbahaya berupa nitrogen $\left(\mathrm{N}_{2}\right)$ cair, peralatan tajam seperti mesin chopper, sabit dan parang yang dapat berisiko melukai pekerja. Pembuangan limbah dan kotoran yang dihasilkan ternak yang ada di BIB Lembang ditampung pada kolamkolam khusus yang telah disediakan dan diproses lebih lanjut untuk dimanfaatkan menjadi biogas dan pupuk kompos untuk lahan hijauan. Kebersihan kandang dan ternak selalu terjaga dan rutin dilakukan pembersihan sehingga menjamin kesehatan ternak dan pekerja.

Penilaian risiko dan bahaya dari potensi kecelakaan kerja pada Tabel 3 di atas dianalisis secara semi kuantitatif (Ramli, 2010a). Hasil Penilaian risiko dan bahaya dari potensi kecelakaan kerja pada beberapa pekerjaan di kandang sapi potong PT. X disajikan pada Tabel 4.

Hasil penilaian risiko dari Tabel 4 adalah diperoleh sebanyak 31 potensi bahaya yang dapat menyebabkan kecelakaan kerja pada enam pekerjaan di kandang sapi potong PT. X. Tidak ditemukan potensi bahaya dengan risiko kategori tinggi, terdapat 13 potensi bahaya dengan risiko kategori sedang dan 18 potensi bahaya dengan risiko kategori rendah. Hasil penelitian ini lebih sedikit jika dibandingkan dengan (Pranamyaditia, 2017), yang melaporkan hasil identifikasi bahaya di peternakan sapi potong PT. X di Kota Kediri sebanyak 49 potensi bahaya pada delapan pekerjaan yaitu pada saat mencari dan mencacah rumput memindahkan sapi, mencampur pakan konsentrat, pembersihan kandang, pengolahan limbah, pemeriksaan kesehatan sapi dan pemeliharaan atau perbaikan kandang. Perbedaan ini karena pada penelitian 
ini berfokus terhadap kecelakaan akibat kerja, sedangkan pada penelitian sebelumnya oleh Pranamyaditia (2017), juga menghitung potensi bahaya terhadap kesehatan kerja dari delapan pekerjaan di kandang sapi potong, yaitu seperti adanya ancaman cacing parasite, alergi, dan penyakit kulit akibat paparan radiasi sinar matahai pada pekerjaan mencari dan mencacah rumput, kemudian tertular penyakit dan keracunan gas metane pada pekerjaan memeriksa kesehatan sapi, membersihkan kandang, dan mengolah kotoran sapi. Hasil penilaian (Pranamyaditia, 2017) terhadap 49 potensi bahaya dari delapan pekerjaan, diperoleh kategori risiko rendah sebanyak 36 , kategori risiko sedang 10 dan kategori risiko tinggi sejumlah tiga yaitu risiko tertendang sapi pada pekerjaan membersihkan kandang dan maintenance kandang serta risiko pencemaran lingkungan pada pekerjaan membersihkan kandang

Tabel 4. Penilaian bahaya dan risiko yang berpotensi terjadi kecelakaan kerja pada beberapa pekerjaan di kandang sapi potong PT. X

\begin{tabular}{|c|c|c|c|c|c|c|c|c|}
\hline \multirow{2}{*}{ No } & \multirow{2}{*}{ Pekerjaan } & \multirow{2}{*}{ Potensi bahaya } & \multicolumn{3}{|c|}{ Resiko } & \multicolumn{3}{|c|}{ Nilai resiko } \\
\hline & & & $\mathrm{L}$ & $\mathrm{S}$ & RR & $\operatorname{Re}$ & $\mathrm{Sd}$ & $\mathrm{Ti}$ \\
\hline \multirow[t]{6}{*}{1} & Handling & Tertanduk & 3 & 3 & 9 & & V & \\
\hline & sapi & Tertendang & 4 & 3 & 12 & & $\vee$ & \\
\hline & & Terinjak & 2 & 3 & 6 & & v & \\
\hline & & Terhimpit & 2 & 1 & 2 & V & & \\
\hline & & Terpeleset & 2 & 2 & 4 & V & & \\
\hline & & Terlilit tali & 1 & 1 & 1 & V & & \\
\hline \multirow[t]{5}{*}{2} & Penyediaan & Tertusuk & 2 & 1 & 2 & $\mathrm{~V}$ & & \\
\hline & pakan hijauan & Kebakaran & 1 & 4 & 4 & V & & \\
\hline & & terpeleset & 4 & 2 & 8 & & $\vee$ & \\
\hline & & Kelilipan & 3 & 2 & 6 & & V & \\
\hline & & Serangan sapi & 3 & 2 & 6 & & V & \\
\hline \multirow[t]{5}{*}{3} & Penyediaan & Terhirup debu pakan & 4 & 2 & 8 & & $\mathrm{~V}$ & \\
\hline & pakan & Gangguan serangga & 2 & 1 & 2 & v & & \\
\hline & konsentrat & Kelilipan & 3 & 2 & 6 & & V & \\
\hline & & Terpeleset & 2 & 2 & 4 & V & & \\
\hline & & Serangan sapi & 2 & 2 & 4 & & V & \\
\hline \multirow[t]{4}{*}{4} & Pembersihan & Terpeleset & 2 & 2 & 4 & V & & \\
\hline & kandang & Serangan sapi & 2 & 2 & 4 & & $\vee$ & \\
\hline & & Terhirup bau tidak sedap & 4 & 1 & 4 & V & & \\
\hline & & Keracunan gas & 1 & 4 & 4 & V & & \\
\hline \multirow[t]{6}{*}{5} & Perawatan & Tertusuk jarum suntik & 1 & 1 & 2 & V & & \\
\hline & kesehatan & Tertanduk & 3 & 3 & 9 & & V & \\
\hline & sapi & Tertendang & 3 & 3 & 9 & & $\vee$ & \\
\hline & & Terinjak & 3 & 3 & 9 & & V & \\
\hline & & Terhimpit & 3 & 1 & 4 & V & & \\
\hline & & Terpeleset & 2 & 2 & 4 & $\vee$ & & \\
\hline \multirow[t]{5}{*}{6} & Perawatan & Terjatuh & 1 & 2 & 2 & V & & \\
\hline & kandang & Tertimpa bangunan & 1 & 3 & 3 & V & & \\
\hline & & Tersetrum & 1 & 3 & 3 & V & & \\
\hline & & Tertusuk & 2 & 1 & 2 & V & & \\
\hline & & Terpukul palu & 2 & 1 & 2 & $\vee$ & & \\
\hline
\end{tabular}


Program K3 berperan besar dalam pengendalian risiko dan sebagai upaya mencegah tingkat keparahan suatu kecelakaan. Berdasarkan penilaian risiko dari 31 potensi bahaya (Tabel 4) perlu dilakukan pengendalian oleh manajemen dan pekerja. Namun demikian, masih membutuhkan perbaikan tingkat bahaya untuk meminimalisir dampak terhadap keselamatan pekerja. Menurut Ramli (2010b), pengendalian potensi bahaya belum mampu dalam mengurangi risiko yang ada sepenuhnya. Masih ada kemungkinantimbulnya kecelakaan akibat kerja sehingga diperlukan Langkahlangkah dan upaya perbaikan pengendalian tersebut. Risiko yang membutuhkan perbaikan harus mendapat perhatian lebih besar supaya tidak merugikan pekerja di peternakan sapi potong. Sejumlah 13 risiko dengan kategori sedang memerlukan perhatian lebih pada pekerjaan handling sapi, penyediaan pakan hijauan dan konsentrat, pembersihan kandang dan perawatan Kesehatan sapi serta perawatan kandang. Penjelasan di atas memberi gambaran bahwa pengendalian risiko sangat dibutuhkan dengan kaitanya sebagai upaya menghilangkan risiko yang ada. Perlu adanya peningkatan perhatian oleh perusahaan terhadap keselamatan dan kesehatan kerja pada pekerjanya. Hal ini sesuai dengan pendapat Paramitha dan Wijayanto (2012), bahwa K3 sangat berpengaruh positif terhadap produktivitas dan kinerja para pekerja, kinerja tersebut ditunjukkan dalam motivasi kerja dan prestasi kerja sehingga berdampak pada keuntungan perusahaan.

Pencegahan (pengendalian) bahaya dan risiko dari potensi kecelakaan kerja pada beberapa pekerjaan di kandang sapi potong hanya mempergunakan atau mengenakan APD (alat pelindung piri) dan tali pengikat atau penuntun padasapi. Alat pelindung diri merupakan upaya terakhir dari perusahaan untuk mengurangi atau menghilangkan risiko, dengan demikian pengendalian risiko dengan menggunakan APD berhubungan erat dengan terjadinya kecelakaan kerja (Handayani et al., 2010). Pengendalian risiko bahaya perlu dinilai sehingga dapat disusun program prioritas pengendalian yang harus dilakukan perusahaan. Pengendalian risiko tidak mungkin seluruhnya dapat dihilangkan namun sangat mungkin dapat diminimalisir atau dikurangi. Pengendalian/penanganan sangat penting untuk dilakukan sesuai dengan prioritas (hasil penilaian risiko). Menurut Ramli (2010b), bahwa dalam keseluruhan manajemen risiko, pengendalian risiko merupakan langkah yang nantinya akan sangat menentukan. Strategi dalam pengendalian risiko $\mathrm{K} 3$ dapat dilakukan dengan langkah-langkah sebagai berikut: menekan kemungkinan kejadian, menekan konsekuensi kejadian dan pengalihan risiko itu sendiri. Secara teori K3, berbagai upaya yang dapat dilakukan dalam pengendalian risiko dan bahaya K3 seperti pada Gambar 1 .

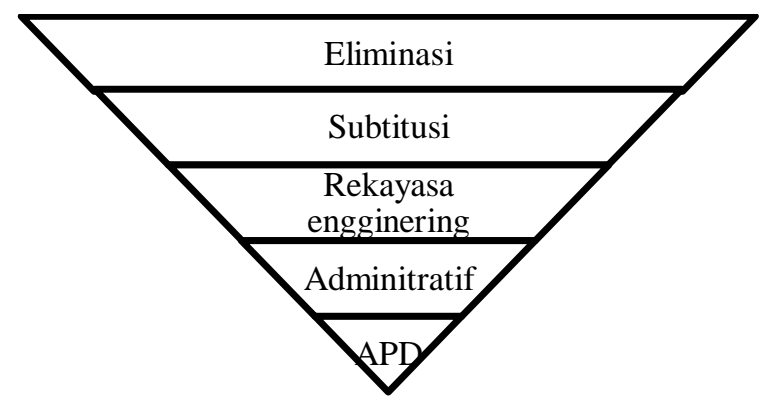

Gambar 1. Hirarki pengendalian risiko (Ramli, 2010b) 
Di beberapa pekerjaan di kandang sapi potong PT. X sebagian besar pekerja pada umumnya jarang mengetahui dan mendengar tentang K3. Berbeda halnya dengan kegiatan industri lainnya misalnya di dalam pabrik maupun tempat produksi lainnya. Seperti yang dilaporkan oleh Yuliandi dan Ahman (2019), pada pekerjaan di kandang sapi potong di BBIB Lembang penggunaan APD wajib digunakan oleh seluruh pekerja di kandang pada pekerjaan pemeliharaan ternak baik oleh medik veteriner, paramedik veteriner, perawat ternak dan petugas yang berada di kandang berupa pemakaian masker, lattex gloves, sapatu kandang, wearpack, apron, kacamata pelindung, dan helm. Mengingat BBIB Lembang merupakan lembaga dibawah Kementerian Pertanian Republik Indonesia sehingga penerapan K3 menjadi sangat penting dan wajib dipatuhi oleh semua pekerja. Berbeda dengan yang dilaporkan oleh (Dayana et al., 2019), bahwa penerapan K3 oleh juru sembelih halal dan seluruh pekerja di Rumah Potong Hewan-Ruminansia (RPH-R) Mambal dan Pesanggaran, Kota Denpasar masih belum dipahami dan diterapkan sesuai dengan standar yang ada yaitu SNI 01-6159-1999.

Pekerja pada beberapa pekerjaan di kandang sapi potong jarang untuk dilibatkan dan mengikuti pelatihan kompetensi yang terstandar seperti Badan Nasional Sertifikasi Profesi (BNSP) atau Lembaga Sertfikasi Profesi Indonesia (LSPI). Perlu adanya sosialisasi yang berkaitan dengan K3 mengingat pentingnya keselamatan dan keamaanan di kandang sapi potong. Hal ini sesuai dengan Soelaiman, (2007), yang berpendapat bahwa kinerja adalah sesuatu yang dikerjakan oleh seseorang atau sekelompok orang untuk menghasilkan produk maupun jasa pada suatu periode tertentu dan ukuran tertentu, sesuaty tersebut harus dilakukan dengan kecakapan, kemampuan, pengetahuan dan pengalaman. Selain itu, pentingnya informasi K3 kepada pekerja di kandang sapi potong perlu diperhatikan. Pimpinan dan manajemen di perusahaan atau kandang peternakan sapi potong wajib memberikan jaminan keamanan dan kesehatan bagi pekerjanya. Sesuai dengan Gambar 1, maka beberapa upaya pengendalian dan pencegahan risiko kecelakaan kerja pada beberapa pekerjaan di kandang sapi potong PT. $\mathrm{X}$ adalah sebagai berikut:

1. Kesadaran penggunaan APD (wearpack, sepatu kandang, penutup kepala, masker, sarung tangan)

2. Kesadaran untuk bekerja sesuai standart operating procedure (SOP) yang ditentukan (teratur dan rapi)

3. Pemeriksaan alat dan mesin secara reguler dan memastikan semua dalam kondisi yang aman

4. Menjaga kondisi kandang tetap bersih dan nyaman

5. Mengenal karaktersitik/behavior sapi

Penggunaan APD adalah tahapan terakhir dalam pengendalian kecelakaan maupun penyakit akibat kerja. Meskipun demikian, penggunaan APD akan menjadi utama dan penting jika telah dilakukan pengendalian secara teknis dan administratif secara maksimal, akan tetapi masih dalam kategori potensi risiko tinggi. Namun demikian, masih banyak pekerja di kandang sapi potong 
yang tidak mengenakan dan menggunakan APD. Hal ini terlihat dari beberapa hasil penelitian yang melaporkan bahwa ada pekerja yang telah mengalami kecelakaan kerja di kandang sapi potong. Kecelakaan kerja merupakan hal yang tidak diinginkan oleh semua orang dan tidak diketahui kapan terjadinya. sehingga dibutuhkan adanya antisipasi. Ada berbagai cara untuk meminimalisir terjadinya kecelakaan kerja, salah satunya dengan meningkatkan kebiasaan pemakaian APD pada saat proses produksi. Tingkat keselamatan kerja sangat dipengaruhi oleh tingkat penggunaan APD. Handayani et al. (2010), menyatakan bahwa penggunaan APD berhubungan erat dengan kecelakaan kerja yang dialami pekerja dengan koefisien korelasi sebesar $r=0,421$. Hal ini menunjukan bahwa 17,7\% penggunaan APD mampu berkontribusi pada pencegahan terjadinya kecelakaan kerja. Tingkat penggunaan APD yang semakin rendah, memberi kesempatan terjadinya kecelakaan kerja yang semakin besar. Kondisi yang aman dari kemungkinan terjadinya kecelakaan kerja akan meningkatkan kinerja perusahaan dapat menjaga kesehatan dan keselamatan kerja pekerja maupun pada ternak sapinya. Putri (2017) menyatakan bahwa pendidikan dan sikap terhadap kebijakan perusahaan menjadi faktor yang mempunyai hubungan signifikan dengan kepatuhan dalam penggunaan APD dengan nilai $r=0,336$ dan $r=$ 0,233. Sementara Adiputro (2019) menyatakan bahwa pengetahuan dan motivasi berhubungan kuat dengan kepatuhan dalam penggunaan APD dengan nilai $r=0,607$ dan $r=0,600$. Dengan demikian, dimungkinkan kepatuhan dalam penggunaan APD oleh pekerja di kandang sapi potong PT. X juga dapat dikorelasikan dengan beberapa faktor tersebut yaitu pendidikan/pengetahuan.

Kesadaran untuk bekerja sesuai SOP yang ditentukan (teratur dan rapi), hal ini berkaitan dengan SOP yang sudah dibuat oleh perusahaan dengan pertimbangan $\mathrm{K} 3$ bagi pekerjanya maupun bagi sapinya itu sendiri. Namun demikian, kenyataannya masih banyak juga pekerja di kandang sapi potong yang tidak mengikuti SOP yang dibuat, walaupun telah diketahui bersama bahwa bekerja sesuai dengan SOP dapat mengeliminasi adanya risiko dan bahaya kecelakaan kerja. Seperti beberapa hasil penelitian yang melaporkan bahwa ada pekerja yang telah mengalami kecelakaan kerja di kandang sapi potong (Pranamyaditia, 2017). Menurut Putri dan Martiana (2018), pemberian reward dan punishment dapat meningkatkan perilaku pekerja dalam menjalankan safety training observation program (STOP). Sebagian besar $(80 \%)$ tenaga kerja memiliki perilaku yang baik dalam menjalankan STOP, terdapat hubungan (dengan nilai koefisien korelasi 0,689 ) antara reward berupa intensif oleh perusahaan dan hubungan (dengan nilai koefisien korelasi -0,293) antara punishment berupa penuruan gaji dengan perilaku pekerja menjalankan STOP dengan baik. Sehingga bisa dijadikan bahan intervensi oleh perusahaan dalam meningkatkan perilaku pekerja dalam menjalankan STOP atau SOP dari K3 itu sendiri.

Pemeriksaan alat dan mesin secara reguler dan memastikan semua dalam kondisi yang aman. Mesin-mesin atau peralatan- 
peralatan dalam kandang peternakan sapi potong biasanya terdiri dari mesin pencacah rumput (chopper), mesin pencampur pakan (mixer) dan timbangan. Mesin-mesin tersebut terhubung dengan jaringan listrik, atau bisa juga mesin yang menggunakan penggerak mesin diesel. Sementara untuk peralatan standar adalah sabit, parang, sekop, serok, selang, Potensi bahaya dari penggunaan mesin dan peralatan pada peternakan sapi potong dapat diantisipasi dan diminimalisir dengan melakukan pembersihan, perawatan, dan pengecekan secara berkala tergantung dengan intensitas penggunaannya. Apabila menemukan malfungsi dapat segera dilaporkan ke penanggung-jawab dan membuat catatan, kemudian dalam pengoperasiannya wajib mengikuti prosedurnya.

Menjaga kondisi kandang tetap bersih dan nyaman, tentu saja akan dapat meminimalisir risiko kecelakaan kerja seperti terpeleset, menghirup bau tidak sedap, keracunan dan lain sebagainya. Kandang dan lingkungan yang bersih akan membuat pekerjaan menjadi nyaman. Tidak hanya bagi pekerja, namun kebersihan kandang juga berdampak terhadap kenyamanan ternak sapi itu sendiri. Mengenal karaktersitik/behavior ternak (sapi), sapi adalah hewan penakut, sehingga selalu waspada dan berjaga-jaga apabila ada yang mendekatinya terlebih yangtidak dikenalnya. Apabila memasuki kandang sapi agar tetap berhati-hati, melangkah perlahan, tidak berisik atau berlari-lari agar sapi tidak kaget dan panik.

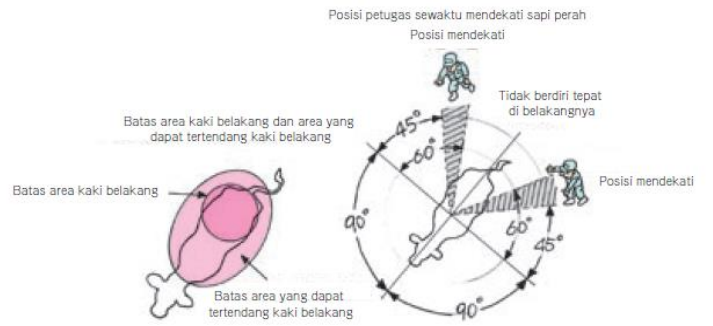

Gambar 2. Ilustrasi zona aman dan bahaya pada sapi (Jitco, 2013)

Gambar 2 merupakan ilustrasi zona aman dan bahaya sewaktu mendekati sapi. Bahaya tertendang atau terinjak sapi, sebagian besar terjadi pada kaki belakang sapi. Area yang dapat ditendang terdapat pada sekitar kaki belakang, sehingga hindari menghampiri dan mendekati sapi pada area tersebut. Apabila ingin memindahkan sapi, datanglah dari samping belakang dan dapat dilihat oleh sapi. Dengan mengetahui risiko bahaya tersebut maka pekerja dapat lebih berhati-hati dan bisa meminimalisir risiko bahaya tersebut sehingga nantinya dapat terhindar atau dapat meminimalisir risiko bahaya yang dapat terjadi di kandang sapi potong PT. X.

Pencegahan dan pengendalian bahaya dan risiko dapat diupayakan dengan perbaikanperbaikan infrastuktur (sarana) dan manajemen (SOP) kerja. Menurut Dharma et al. (2017), dalam menurunkan dampak risiko $\mathrm{K} 3$ harus dilakukan pengendalian risiko, dilakukan evaluasi secara terjadwal dan periodik, mempertimbangan jarak aman dari sumber bahaya dengan pekerja, mengaturjam kerja, menetapkan prosedur skenario dan evakulasi dalam kondisi darurat, serta menerapkanintruksi kerja yang jelas. Soputan et al. (2014) menyatakan bahwa beberapa upaya untuk mengurangi risiko yaitu dengan 
melakukan rekayasa teknik, administratif dan penggunaan APD.

\section{KESIMPULAN DAN SARAN}

Berdasarkan hasil penelitian studi kasus, dapat disimpulkan bahwa di PT. X terdapat 6 pekerjaan di kandang sapi yang dapat menimbulkan sebanyak 31 potensi bahaya dengan risiko rendah (18) dan sedang (13). Selain itu, upaya penerapan keselamatan dan kesehatan kerja masih minim, belum ada SOP K3 dari manajemen/pimpinan perusahaan dan penerapan K3 oleh pekerja hanya sebatas penggunaan APD (sepatu kandang). Hal ini berakibat terhadap potensi bahaya dan risiko kecelakaan kerja sangat mungkin terjadi. Disarankan untuk manajemen PT. X menyusun SOP K3, mensosialisasikan, menerapkan pada seluruh pekerja dan melakukan pengawasan, monitoring dan evaluasi terhadap penerapan SOP K3. Pekerja kandang diharapkan selalu menggunakan APD setiap melakukan pekerjaan. Hal ini penting agar dapat pencegahan risiko dan bahaya kecelakaan kerja pada saat melakukan pekerjaan.

\section{UCAPAN TERIMA KASIH}

Terima kasih kepada pimpinan, manajemen, danpekerja PT. X, Boyolali yang telah mengijinkan dan mendukung penelitian ini.

\section{DAFTAR PUSTAKA}

Adiputro, Y. (2019). Relationship between motivation, knowledge, and availability with the use of personal protective equipment. The Indonesian Journal of Occupational Safety and Health, 8(2), 124-130.

https://doi.org/10.20473/ijosh.v8i2.2019. 124-130
Agbola, R. M. (2012). Impact of health and safety management on employee safety at The Ghana Ports and Harbour Authority. Developing Country Studies, 2(9), 154166.

Dayana, A. A. P. I., Rudyanto, M. D., \& Suada, I. K. (2019). Aplikasi kesehatan dan keselamatan kerja (K3) pada juru sembelih halal dan pekerja pemotong daging di Rumah Pemotongan Hewan Mambal dan Pesanggaran. Indonesia Medicus Veterinus, 8(1), 99-105. https://doi.org/10.19087/imv.2019.8.1.99

Dharma, A. A. B., Putera, I. G. A. A., \& Parami, A. A. D. (2017). Manajemen risiko keselamatan dan kesehatan kerja (K3) Pada proyek pembangunan Jambuluwuk Hotel \& Resort Petitenget. Jurnal Spektran, 5(1), 47-55. https://doi.org/10.24843/spektran.2017.v 05.i01.p06

Handayani, E., Wibowo, T. A., \& Suryani, D. (2010). Hubungan antara pengunaan alat pelindung diri, umur dan masa kerja dengan kecelakaan kerja pada pekerja bagian rustic di PT Borneo Melintang Buana Eksport Yogyakarta. Kesmas Journal UAD, 4(3), 208-217. http://journal.uad.ac.id/index.php/KesMa s/article/view/1092

Jitco. (2013). Keamanan dan Kesehatan Kerja untuk Peserta Praktik Kerja di Bidang Industri Peternakan. Japan International Trainee \& Skilled Worker Cooperation Organization. Tokyo. https://www.jitco.or.jp/download/data/tex t/chikusan_Indonesia.pdf

Machabe, A. P., \& Indermun, V. (2013). An overview of the occupational health and safety act: A theoretical and practical global perspective. Arabian Journal of Business and Management Review, 3(5), 13-33.

Peraturan Menteri Tenaga Kerja Republik Indonesia Nomor 05/MEN/1996 Tentang Sistem Manajemen Keselamatan dan Kesehatan Kerja, Pub. L. No. 05/MEN/1996 (1996). 
Oketunji, S. F. (2014). Influence of occupational health and safety (OHS) information availability and use on job performance of library personnel in public universities in South-West Nigeria. European Scientific Journal, 10(14), 337350.

Paramitha, C. C. P., \& Wijayanto, A. (2012). Pengaruh keselamatan dan kesehatan kerja terhadap prestasi kerja karyawan pada PT. PLN (Persero) APJ Semarang. Jurnal Administrasi Bisnis, 1(1), 1-11. https://doi.org/10.14710/jab.v1i1.4313

Pranamyaditia, C. D. (2017). Risiko keselamatan dan kesehatan kerja pada pekerja peternakan sapi di PT X cabang Kota Kediri. The Indonesian Journal of Occupational Safety and Health, 5(1), 110.

https://doi.org/10.20473/ijosh.v5i1.2016. $1-10$

Putri, K. D. S. (2017). Analisis faktor yang berhubungan dengan kepatuhan menggunakan alat pelindung diri. The Indonesian Journal of Occupational Safety and Health, 6(3), 312-322.

Putri, R. W., \& Martiana, T. (2018). Hubungan reward dan punishment dengan perilaku tenaga kerja dalam menjalankan program STOP. The Indonesian Journal of Occupational Safety and Health, 7(2), 172-180. https://ejournal.unair.ac.id/IJOSH/article/downlo $\mathrm{ad} / 5037 / \mathrm{pdf}$

Ramli, S. (2010a). Pedoman Praktis Manajemen Risiko dalam Perspektif K3 OHS Risk Management. PT. Dian Rakyat.

Ramli, S. (2010b). Sistem Manajemen Keselamatan \& Kesehatan Kerja OHSAS 18001. PT. Dian Rakyat.

Rijanto, B. (2011). Keselamatan, Kesehatan Kerja dan Lingkungan Industri Konstruksi ( $2^{\text {nd }}$ ed.). Mitra Wacana Media.

Soelaiman, S. (2007). Manajemen Kinerja: Langkah Efektif untuk Membangun, Mengendalikan dan Evaluasi Kerja $\left(2^{\text {nd }}\right.$ ed.). PT. Intermedia Personalia Utama.
Soputan, G. E. M., Sompie, B. F., \& Mandagi, R. J. M. (2014). Manajemen risiko keselamatan dan kesehatan kerja (K3) (Studi kasus pada pembangunan gedung SMA Eben Haezar). Jurnal Ilmiah Media Engineering, 4(4), 229-238.

Yuliandi, C. D., \& Ahman, E. (2019). Penerapan keselamatan dan kesehatan kerja (K3) di lingkungan kerja Balai Inseminasi Buatan (BIB) Lembang. Manajerial, 18(2), 98-109. 